\title{
The Construction of Professional Knowledge: A Comparative Study of Social Assistants and Mediators
}

\author{
Ana Maria Costa e Silva, PhD \\ Institute of Education and CECS ${ }^{1}$, University of Minho, Portugal \\ email: anasilva@ie.uminho.pt
}

\section{Doi:10.5901/jesr.2014.v4n2p191}

\section{Abstract}

This work is centred on the dynamics of identity and professional development of two socio-professional groups; namely, Social Assistants and Mediators. It takes as its point of departure the characterisation of these socio-professional groups and their professionalization. The professionalization of the social groups matches the dynamics of identity development and presupposes social recognition of their professional knowledge and competences that are built in situations of real work and professional socialization (Dubar, 1997; Wittorski, 2008). Schön's (1996) "epistemology of professional practice" is paramount in this context, as theoretical knowledge and learning developed in formal training settings are insufficient for their professional daily work. The study of a qualitative nature was carried out using case studies in four countries - two in Europe and two in Latin America - Portugal, France, Brazil and Argentina. It had as its principal objectives the identification and analysis of the dynamics of identity and their articulation with the construction of professional knowledge in two socio-professional groups, which have been the subject of an increasing social visibility. The research strategies that we favoured were phenomenological and ethno-methodological, which turned out to be the two fundamental techniques for collecting information; namely, documentary research and biographical interviews. This methodology allowed us access to the socio-historical processes and subjective experiences of the participants with respect to their dynamics of professionalisation and in this way we could understand better the continuities and/or gaps in the processes in relation to their construction of identity. In order to analyse the data collected we turned to the emerging characterisations, a structural analysis of discourses and continuous comparison, when searching for evidence in the construction of the interpretative text. As the principal results of the study, we would stress the singularity of each one of these socio-professional groups taking into account their origins, their socio-historical processes and the theoretical and ethical assumptions that have structured their identities. Taking, as a reference, the geographical and cultural variable, it was not possible to find any significant differences in or between any of the groups, which indicates a consistent specific and cross-disciplinary professional ethos. Also evident was the particularity and relevance of professional knowledge in the assertion and professional development of both the Social Assistants and the Mediators.

Keywords: Professional Knowledge, Social Service, Mediation, Dynamics of Identities.

\section{Introduction}

The studies about the processes of professionalization recognize three fundamental dimensions and structuring of professional groups: specialization (specific activity), structure (mobilization of characteristic knowledge) and professionalism (particular function) (Demazière \& Gadéa, 2009). These three dimensions are interactive and are connected with learning and professional knowledge.

Professionalization is a process of updating and renewal of the epistemological foundations of a profession and the training for its practice (Tardif, 2000), through which professional knowledge represents one of the essential elements for the visibility of professional groups and the expression of professionalism of the individuals, who are part of that group.

According to Roche (1999, p. 35), questions related to professionalization gain special relevance "in the moment in which knowledge does not guarantee in a linear way the competency or professionalism of individuals in an economic and social context that knows profound changes". From this it is important to pay attention to: i) questions of professional development in close relationship to the processes of external and internal change for the subjects, who appeal, among other things, to the acquisition and mobilization of the many experiences incorporated in competencies suited to the complexity of their contexts and situations; ii) training and lifelong learning; iii) formal initial training and continuous

${ }_{1}^{1}$ Translation financed by CECS (Centre for Studies in Communication and Society) from National Funds distributed by FCT (Foundation for Science and Technology) in relation to the Strategic Project No. PEst-OE/COM/UI0736/2013 
training in its many contexts and iv) reflective practices.

In this domain, one can highlight the contributions of the field of Educational Sciences and, in particular, Psychology of Education, Pedagogy, Curricular Studies and the Sociology of Education. These fields raise questions about training and learning in articulation with models of learning in adults, reflective practices and social, personal and professional development and also the construction of identity with particular reference to the works of Dominicé (1990), Zeichner (1993), Schön (1996), Barbier (1996), Boutinet (1998), Pastré (2011) and Sacristán (2013).

The study presented here focuses on two professional groups: Social Assistants and Mediators. Although their processes of professionalization are distinct, the professionals of both groups recognize the importance of professional knowledge in their daily work and in their socio-professional visibility.

\section{Professional Knowledge: Theoretical Standing and Condition of Identity}

The situations that characterize current contexts - social, organizational and professional - are incompatible with an initial training for the whole of life and with enrolled models of training that have an exclusive technical, instrumental and objective rationality. The scientific-technical solutions for problems of another nature lead often to disregard, in the training processes, of the reflective dimension about the psychological and socio-institutional mechanisms, which structure representations and professional identities.

Boutinet (1985, p. 13) emphasizes, in this respect, that "if we limit ourselves solely to thinking about (professional) pre-training we lay ourselves open to how difficult is the connection between proposed technical learning and the evolutionary demands of occupations and professions. For many years these occupations enjoyed a remarkable stability. Now this is not the case today". On the other hand, the "reflective practice movement" (Zeichner, 1993) highlights the importance of reflection in and about professional practices, as well as the necessity of educating for the construction and production of knowledge. Schön (1996) refers to this in the same way, when he substantiates the importance of reflection and advocates an 'epistemology of professional action', as a synthesis of the dichotomy between theoretical and practical knowledge or, according to him, the dilemma of rigor and relevance. According to the author (Idem, p. 205), the model of applied sciences appears incomplete for explaining practical competencies in divergent situations by proposing in its place "an epistemology of professional action that is implicit in the artistic and intuitive process and which some practitioners make concerning participation in situations of uncertainty, instability, singularity and conflict of values".

To be or become a professional corresponds to integration in a particular group that claims knowledge and competencies and aspires to be efficient, responsible, autonomous and competent (Demazière, 2009). This way, professional identities are, simultaneously, the result of representations about professional practices and contexts and fundamental resources in these same practices, thus assuming particular importance for training and learning in this dynamic of the constructing and reconstructing of identities.

Also the articulation between theoretical and practical knowledge and the possibility and capacity for reflecting about professional practice, individually and jointly; namely, with work colleagues, are important conditions in the construction of professional knowledge. Reflection becomes an essential element in the development of experience in articulation with the construction of identity and the revelation of a 'capable subject' (Pastré, 2011, p. 124) - "a subject, who position him/herself through action before positioning him/herself with knowledge and who uses this knowledge, as a resource for guiding his/her action".

The professionalization path of Social Assistants and Mediators enroll both socio-professional groups in a process in which professional action precedes specific and specialized training. In this sense, although knowledge of action has preceded training certified specifically for such action, we know that specialized training of quality, certified and recognized and which can be communicated socially and professionally is a relevant condition in the processes of the professionalization of socio-professional groups and of their social and professional recognition. This aspect is especially important both in the competitive context of the market for work and employment and for the professional groups studied here, to a great extent. Competition between them for the socio-professional spaces that they occupy, for the knowledge that they mobilize or say they mobilize and for the recognition that they dispute at the social level exists. Once that they register themselves in a large group designated as 'social workers', they are heterogeneous at the level of training, status, career and positions occupied (Ion \& Tricart, 1985; Autés, 1999; Chauvière \& Tronche, 2002).

The dynamics of professionalization of both socio-professional groups correspond to distinctive processes, which come across nowadays in contexts of group assertion and visibility, which are also different. However, they share objetives and socio-professional spaces with common frequency. Moreover, both are registered in the designated 'professions of relationship and service' (Gorz, 1991; Autés, 1999; Dubet, 2002; Silva, 2003), which value moral qualities 
"founded on a professional habitus shaped by qualities of the subject" (Silva, 2007, p. 47) and of knowing how to be. The work of the Social Assistants and Mediators, as well as the specific competencies of their participation, have a large component of indeterminateness, which are accompanied by a difficult objectifiation and measurability both inside and outside of the professional group.

These characteristics of professionalism of both groups allows them to carry out their duties with a certain level of autonomy but it makes harder their objetification and the legitimization of their practices (Silva, 2007). This is a rationality particularly valued in the competitive society in which we live but one which is connected "in a way that is contradictory with the logic of professionalism founded on service and objective delivery" (Silva, 2007, p. 47). According to Gorz (2001), social work belongs to the category of activities that, though they create a value of use in the market, are impossible to measure or to maximize profit, since they define their acts and objectives according to the needs of others.

The work of Social Assistants and Mediators is marked by the art of personal contacts and relationships (Ion \& Tricart, 1984) that, when integrated in the framework of bureaucratic organizations, like Social Security or Justice, ends up by translating itself into administrative-relational know-how in the interface between the world of regulations and every day life (Ion \& Tricart, 1984; Silva, 2007). This explains the difficulty that these professionals have in stating what they do - a "structural difficulty or impossibility, which is related with the construction of practices in which the purpose finds itself profoundly linked to the strategy of action" (Silva, 2007, p. 48). In this comparative study between Social Assistants and Mediators, the former favor instrumental objects - communication, dialogue, service, team work, research, whereas the latter identify with objects that are preferentially analytical - analysis, recognition, discovery, construction with bridges, ties and justice, as will be documented in the presentation of the results.

\section{Methodology: Objectives, Methods and Sample}

This investigation focused on the identification of identity dynamics in connection with the construction of professional knowledge and on a comparative analysis between two socio-professional groups: Social Assistants and Mediators. From the objectives of the defined investigation we would highlight the following: i) to identify the working language, professional knowledge, competencies to be learned, mobilized and developed by the professionals; ii) to examine the processes related to the construction of knowledge and expression of professional identities.

A qualitative methodology (Huberman \& Miles, 1991; Denzin \& Lincoln, 1994) was considered and this was guided by the interpretative paradigm. Phenomenology, symbolic interaction and ethno-methodology constituted the principal methodological strategies considered for the gathering, analysis and interpretation of the information. The mobilization and links between different theoretical perspectives, which shared common and complementary methodological features (Tesch, 1990), permitted access to the phenomena under study in distinctive ways and of a more profound nature, through the combining of written information, records of a historical, normative, theoretical and scientific nature with oral, unique, biographical and contextualized information. In the choice of information we favored documental research and in depth biographical interviews. The documental research focused on legal, technical and specifically scientific bibliographic documents about each of the professional groups, which were published in the different countries involve in the study. The biographical interviews centered on specific aspects and moments from the biographies of the subjects interviewed and particularly about feelings about work and the way it was carried out.

The study concerned comparative case studies, of professionals in several countries: Portugal, France, Argentina and Brazil.

Table 1 - Total number of subjects interviewed: by professional group and country

\begin{tabular}{|l|c|c|c|}
\hline \multicolumn{1}{|c|}{ Professional Group Country } & Social Assistants & Mediators & Total \\
\hline Argentina & 5 & 2 & 7 \\
\hline Brazil & 3 & 2 & 5 \\
\hline France & 3 & 4 & 7 \\
\hline Portugal & 3 & 2 & 5 \\
\hline Total & 14 & 10 & 24 \\
\hline
\end{tabular}

Eight case studies were carried out - two in each country - and a total of 24 subjects were interviewed, as shown in Table 1 above. The research covered a sample of maximum variation in which the following indicators were considered: age, sex, training pathway, professional experience and experience of training in the area. 


\section{Results}

\subsection{Knowledge about Professional Activity in the Working Contexts}

The biographical interviews carried out with the Social Assistants and Mediators revealed their difficulty of explaining about their work, which was shown to cover a varied range of activities and the diverse nature of fundamental resources covered by fields of theoretical knowledge, experiential learning, working conditions and personal conditions and characteristics.

Diversity of resources was identified as important for the work that they carried out, which required a balanced appreciation of theoretical knowledge and experiential learning, as well as personal conditions and characteristics (particularly those shown by the Mediators). To these they added in a significant way their working conditions of a variable nature, which reveals the specificity that they recognised in their work and its complexity. This was further reflected in their difficulty of saying what they do, which can - in certain measure - explain knowledge and unspoken learning and its invisibility on the part of Social Assistants and Mediators, which thus affects their social recognition.

Table 2 shows the diversity of resources and the necessary and important learning for the work of Social Assistants and Mediators mentioned in their biographical interviews.

Table 2 - Nature o resources and important working knowledge

\begin{tabular}{|l|c|}
\hline \multicolumn{2}{|c|}{ Social Assistants and Mediators } \\
\hline Nature of Resources & Nature of Learning \\
\hline Theoretical Knowledge & Theoretical and disciplinary learning \\
\hline Experiential Knowledge & Experiential and contextual learning \\
\hline Working conditions & \multirow{2}{*}{ Ethical learning } \\
\hline Personal conditions and characterístics & \\
\hline
\end{tabular}

The previous table identifies a differentiated group of resources that, besides learning of a diverse nature, presumes equality in working conditions and essential individual conditions in the organization and optimization of the real work of these professionals. From the group of necessary conditions identified the following stand out:

- Material conditions - financial resources, institutional resources, human resources and spatial resources.

- Methodological conditions - evaluation, supervision and records; communication; knowledge to deal with differences; personal organization.

- Socio-pedagogical condições - team work; good (co-ordinator) co-ordination of work; freedom to make decisions; professional recognition.

- Ethical-moral conditions - ethical commitment; commitment to the public; to have hope; to be sensitive.

To the diversity of conditions identified, as important for the work that they carried out, they added groups of knowledge of a varied nature that were organized into theoretical knowledge, contextual knowledge and ethical knowledge. The Social Assistants and Mediators emphasized differentiated knowledge. The Social Assistants were guided more by action and intervention and the Mediators were more centered on understanding and communication, which is coherent with the field of activity of each of these profiesional groups.

As one can see, the work of these professionals assumes, besides theoretical and technical knowledge, autonomy and judgment. According to Tardif $(2000, p .7)$, "the matter is not only standardized technical knowledge, whose operational modes are codified and known in advance, for example, in the form of routines, procedures or recipes. On the contrary, their professional knowledge actually demands a bit of improvisation and adaptation to new and unique situations that demand professional reflection and judgment, so that one can not only to understand the problem but organize and clarify the desired objectives and the means to be used to achieve them". In other words, the work presumes a process of production, characterized by a certain degree of indeterminateness and technicality, since these professionals demand not just the mere mobilization of knowledge but the making of judgments in situations of action (Tardif, 2000). In the same sense, Begon and Mairesse (2013, p. 42) recognize that, "in all the activity they progress real processes of creation - more or less hidden or explicit, which gives them a lively and significant character", which is present in the productive and constructive dimension of activities. These activities are expressed through various forms of autonomy that are mobilized by the individual, who inspires their style and generic assumptions of action (Clot, 2008) and which the actor has diffulty in explaining verbally.

The resources, knowledge, learning and actions explained by the Social Assistants and Mediators interviewed 
reveal the multiplicity of conditions that they consider necessary to mobilize in the activities that they develope, which constitute a complex puzzle of diverse pieces that requires creative articulation. That is to say, "the knowledge valued and mobilized in work is connected with the way how they interpret and experience this matter that occurs in the arena of virtuosity of everyday work. Comparison to the world outside and to others reveals the importance of the ethos of virtuosity, while also demonstrating a specific approach to work, the conditions of its realization, as well as knowledge and the possibility of recognition by others - a recognition that is particularly relevant for the dynamic of the construction of identity" (Silva, 2007, p. 167).

Therefore, knowledge acquired in the field of initial training becomes insufficient in the management of everyday work, so the mobilization of an shrewd intelligence (Dejours, 1993) is indispensable for the management of uncertain. unpredictable andunexpected events, which on being experienced need to be shared and puts into words that are not only cognitive appropriations but also affective.

\subsection{Mobilization of Learning and Construction of Professional Knowledge}

The professional knowledge identified by the respondents, which at times was difficult to communicate in an organized, rational and understandable way, remains and recovers itself in the competencies and capacities recognized as necessary by the Social Assistants and Mediators. Returning to what was referred above about the meaning and importance of professionalism, which were taken together as characteristic of professional groups and the individuals, who are integrated in them and their special connection with professionalization, various authors refer to the way how the people work (Bourdoncle, 1991; Chauvière \& Tronche, 2002; Dubar, 2002) and particularly to the capacities, competencies, rationalization of knowledge, as well as conditions of visibility and affirmation for social recognition. This results in the visibility and the quality of what they do and in their social significance, which was found to be associated with an intention to adapt and adjust to the new times, including the demands of modernization (competition and competitiveness) that both the political-financial and educational representatives appropriate and disseminate. The importance attributed to knowledge mobilized in work and to the qualities of the workers assumes, according to Stroobants (1994), the recognition which for the latter represents an important value.

In the biographical interviews of the Social Assistants and the Mediators, the competencies and capacities identified by both professional groups is - in large measure - coincident knowledge i.e. the capacity to communicate and to listen, the capacity for self-evaluation and the capacity to manage time. Whereas the different capacities highlighted by both groups were: the capacity for planning, negotiation and analysis and capacity of engagement and commitment for the group of Social Assistants and the capacity for empathy, understanding and presentation for the Mediators.

The organization of knowledge, the competencies identified and their allocation to the domains of personal, social and emotional competencies - the domains especially relevant in field of intervention of both professional groups discussed here - can be read in Table 3. This shows that the main tendency is the identification of social competencies for the Mediators and a specific differentiation in the personal competencies of Social Assistants and Mediators, as well as in the emotional competencies, where commitment is especially stressed by the Social Assistant group and understanding by the Mediator group.

Table 3 - Knowledge and Competencies recognized by the Social Assistants and Mediators

\begin{tabular}{|c|c|c|c|c|c|c|}
\hline & \multicolumn{3}{|c|}{ Knowledge } & \multicolumn{3}{|c|}{ Competencies } \\
\hline & Theoretical & Contextual & Ethical & Personal & Social & Ethical \\
\hline SocialAssitants & $\begin{array}{l}\text { Social } \\
\text { sciences; social } \\
\text { service; } \\
\text { educational } \\
\text { sciences }\end{array}$ & $\begin{array}{l}\text { Processual } \\
\text { knowledge; } \\
\text { pratices; } \\
\text { interventional } \\
\text { knowledge }\end{array}$ & $\begin{array}{l}\text { Ethical- } \\
\text { political } \\
\text { knowledge; } \\
\text { social } \\
\text { commitment }\end{array}$ & $\begin{array}{l}\text { Self- } \\
\text { evaluation; } \\
\text { management } \\
\text { of time; } \\
\text { planning; } \\
\text { analysis }\end{array}$ & $\begin{array}{l}\text { Communication; } \\
\text { listening; } \\
\text { negotiation. }\end{array}$ & $\begin{array}{l}\text { Personal } \\
\text { commitment; } \\
\text { respect; } \\
\text { recognition }\end{array}$ \\
\hline Mediators & $\begin{array}{l}\text { Social } \\
\text { sciences; } \\
\text { conmunication } \\
\text { sciences; } \\
\text { educational } \\
\text { sciences }\end{array}$ & $\begin{array}{l}\text { Knowledge } \\
\text { about } \\
\text { interaction; } \\
\text { comnunication } \\
\text { and } \\
\text { understanding }\end{array}$ & $\begin{array}{l}\text { Ethical } \\
\text { knowledge; } \\
\text { relational } \\
\text { commitment }\end{array}$ & $\begin{array}{l}\text { Self } \\
\text { evaluation; } \\
\text { management } \\
\text { of time }\end{array}$ & $\begin{array}{l}\text { Communication; } \\
\text { active listening; } \\
\text { acceptance; } \\
\text { interest and } \\
\text { curiosity about } \\
\text { others; empathy; } \\
\text { knowing how to } \\
\text { present oneself }\end{array}$ & $\begin{array}{l}\text { Understanding; } \\
\text { respect; } \\
\text { recognition }\end{array}$ \\
\hline
\end{tabular}


The linkage between knowledge and the competencies identifiedby the interviews with both socio-professional groups permits one to recognize a continuity betweem knowledge and competencies and to perceive the relationship between contextual knowledge and the social competencies of the Social Assistants and the Mediators, as well as between ethical knowledge and emotional competencies.

The quotations that are transcribed below show how much interaction between the acquisition and mobilization of knowledge is essential in the process of appropriation, reconstruction and improvement in the practices and knowledge required for them to be mobilized:

"Practice is a privileged space, where one can search for knowledge and start this intervention, afterwards it can be
deepened theoretically in the University" (Brazilian Social Assistant).

"The experience of having done the mediation allows me to speak about her in training contexts; thus practice permite us to evaluate and organise our... a new discourse. It is a phase of learning" (Portuguese Mediator).

The words from the interviews reveal the meaning and importanc of the 'epistemology of professional action', which Schön (1996) advocates, and the process considered by them in the acquisition, mobilization, appropriation, production and reconstruction of pertinent knowledge for an action. They verify a special importance of sharing, supervision and reflection, for appropriation and (re)development and an essential condition for the integrated synthesis of theoretical and practical knowledge.

The process of (re)construction of knowledge and competencies identified by the Social Assistants and Mediators interviewed presumes an acquisition of knowledge, the mobilization of knowledge in professional practice, the appropriation of this knowledge for reflection, sharing, supervision and evaluation and reconstruction of knowledge and production of new knowledge in an interactive and dialogical dynamic. According to Pineau (2013), this process translates into a construction in interchange and into the development of a reflexive practice with the production of knowledge of two types: experiential and formal.

The communication, exchange and socialization of knowledge is an aspect especially appreciated by professionals of both groups, giving notice of the continuity and relevance of communication, as well as in their work activities. The activity becomes an "obligatory passage" (Faïta \& Donato, 1998) for the mobilization, appropriation and production of knowledge and competencies.

Professional development is associated with training, learning and the competence of the professionals. As the right designation indicates, it has underlying it the process of construction and development of a responsible, autonomous and competent professional, thus constituting an important element in affirmation and recognition professional identity. Also it is a condition expressed and repeated more and more in official and scientific discourses and by organizations associated with the quality of professional performance and to the expected and visible results of their work. Professional development assumes, besides initial training that permits access to the profession, a continuous updating of necessary and pertinent knowledge for the appropriate carrying out of work and, consequently, for a good professional performance. This performance of the professionals does not only depend on relevant and mobilized knowledge in the real contexts of their activity but also from a set important, material and emotional conditions, which contribute to the organization and rearrangement of knowledge in specific action situations.

The activities of the Social Services and Mediation presume relationships and interaction, attribution of words to reality, which make them operational (Autés, 1999). Their work occurs and is said in words and in communication combined in different ways and tenses of the verbs to speak, listen, communicate, understand, negotiate, analyze, compromise, etc which explains the importance of communication and language (verbal and non-verbal) in their professional actions. Communication constitutes for these professionals what Dubet (2002, pp. 262-263) calls "the salt of the service", "the heroic space", "the place of an authenticity considered impossible in other registers of action", thus making a reference to the professional ethic.

Their work stands back from instrumental rationality, from a strict relationship between means and ends or from the execution of pre-defined and quantifiable acts, It emphasizes a person-to-person relationship and the taking of positions about what is true and what is just (Autés, 1999; Gorz, 2001). In this sense, it falls to stress that Social Assistants and Mediators do not determine "their actions solely according to criteria of efficacy but also by ethical assessments" (Autés, 1999, p. 246). The reference to ethics, which is present in their praxis, involves these professionals personally at the limits of subjectivity, as for Social Assistants they are proved in their ethical-political commitment and for Mediators in their understanding and neutrality. 
The importance attributed to learning and training is strongly associated to its relevance for carrying out real work, thus favoring access to relevant knowledge for action, which constitutes, simultaneously, an opportunity for their professional development and for personal fulfillment.

\section{Conclusions}

Various studies and authors, as mentioned in this article, have shown that knowledge acquired in initial training is not sufficient and, often, becomes impracticable for managing everyday work. The contexts of work are places of experimentation and proof of the capacities and competencies of professionals and of their judgment by others (colleagues, users, hierarchies...). These become 'arenas of skills' and an expression of an 'ethos of virtuosity' (Dodier, 1995) on the part of professionals. Dodier (1995) further stresses even though the work activity is, simultaneously, selfknowledge that one explores by acting and through recognition by others at the same the work contexts are places of production and recognition of knowledge, which is essential in the construction of the identity of people. The work contexts constitute opportunities for the reconfiguration of the knowledge of specialists (scientific knowledge) in more or less original productions that are looking to restore the cognitive complexity of the logic of action.

In the professions that deal with relationships, as is the case of the Social Services and Mediation, it is particularly important to mobilize what Déjours (1993) calls 'shrewd intelligence', which permits the management of the uncertain and unpredictable, which is manifest in unique and/or unexpected happenings. These happenings, which are experienced by the professionals, need to be shared, put into words that express not only cognitive adaptations but also subjective and affective experiences.

What some authors denote as 'communities of practice' (Nóvoa, 2008) or 'commission of cases' and 'supervision' (as referred to by some of the professionals interviewed) are recognized contexts that are especially suited for learning and development of the professional. They are contexts that allow better sharing and understanding of a common language (between workers in the same office), the reflection about an action and the contextualization of knowledge, because they constitute a space-time dimension in which the work becomes the object of words and thinking, reflection and sharing of experiences. In these contexts the feeling of ownership and professional identity grows stronger, which is essential in the appropriation of knowledge, in the transformation of practices and in professional development.

This investigation showed the availability and interest of the professionals for learning and their own professional development, which recognized the necessity of learning more and about diverse domains, as well as the setting of that learning in distinct contexts including formal contexts, such as universities, and in contexts where their work in interaction with colleagues occurs.

The competencies that Social Assistants and Mediators consider relevant to learn about show their enrollment in an epistemology of professional action. This enrollment also reveals that the necessary professional knowledge for the specificity of professional practice is, at the same time, plural and heterogeneous, personalized and positioned (Tardif, 2000). In other words, professional expertise does not give rise to mere applied science but to knowledge that is socially positioned and locally constructed, which needs to be reflected, suitable and shared in the community of the professionals in the same office, so that it can be communicated publicly and have social visibility.

\section{References}

Autés, M. (1999). Les paradoxes du travail social. Paris: DUNOD.

Barbier, J.-M. (1996). De l'usage de la notion d'identité en recherche, notamment dans le domaine de la formation, Éducation Permanente, 128, 11-25.

Begon, E. \& Mairesse P. (2013). Réflexivité et capabilité : la part de création dans l'activité. Éducation Permanente, n¹96, 39-52.

Bourdoncle, R. (1991). La professionnalisation des enseignants : analyses sociologiques anglaises et américaines, Revue Française de Pédagogie, nº 94, 73-92.

Boutinet, J.-P. (1985). Entre Théorie et Pratique, le travail de l'art. In J.-P. Boutinet (Ed.), Du discours à l'action. Paris: L'Harmattan.

Boutinet, J.-P. (1998). L'immaturité de la vie adulte. Paris: PUF. Chauvière, M. \& Tronche, D. (2002). Qualifier le Travail Social. Dynamiques professionnelles et qualité de service. Paris: DUNOD.

Clot, Y. (2008). Travail et pouvoir d'agir. Paris: PUF.

Déjours, C. (1993). Intelligence pratique et sagesse pratique: deux dimensions méconnues du travail réel, Education Permanente n'116/3, 47-70.

Demazière, D. \& Gadéa, C. (2009). Introduction. D. Demazière \& C. Gadéa (Eds.), Sociologie des groupes professionnels. Acquis récentes et nouveaux défis (pp.13-24). Paris: La Découverte.

Demazière, D. (2009). Les figures de la reconnaissance professionnelle de la médiation socioéducative. A. M. Silva \& M. A. Moreira 
(Eds.), Actas do Seminário Mediação Socioeducativa: Contextos e Actores (pp. 1-23). Braga: Universidade do Minho.

Denzin, N. K. \& Lincoln, Y. S. (Eds.) (1994). Handbook of Qualitative Research. California: SAGE

Dodier, N. (1995). Les Hommes et les Machines. Paris: Éditions Métailié.

Dominicé, P. (1990). Les adultes et leurs psychologies, in Histoires de vie comme processus de formation. Paris: L'Harmattan.

Dubar, C. (1997). A Socialização. Construção das Identidades Sociais e Profissionais. Porto: Porto Editora.

Dubar, C. (2002). Professionnalisation, qualification et compétences. Genèse des notions. In M. Chauvière e D. Tronche, Qualifier le Travail Social. Dynamiques professionnelles et qualité de service, (pp. 74-78). Paris: DUNOD.

Dubet, F. (2002). Le Déclin de l'Institution. Paris: Editions du Seuil.

Faïta, D. \& Donato, J. (1998). Langage et travail : entre compréhension et connaissance. Y. Schwartz (Ed.) Reconnaissances du travail. Pour une approche ergologique (pp.149-170). Paris: PUF.

Gorz, A. (1991). Métamorphoses du travail Quête du sens. Critique de la raison économique. Paris: Galilée.

Huberman, M. \& Miles, M. (1991). Analyse des données qualitatives. Recueil de nouvelles méthodes. Bruxelles: De Boeck Université.

Ion, J. \& Tricart, J.-P. (1984). Les travailleurs sociaux. Paris: Editions la Découverte.

Ion, J. \& Tricart, J.-P. (1985). Une entité professionnelle problématique : les travailleurs sociaux, Sociologie du Travail, n²-1985, 137153.

Nóvoa, A. (2008). O regresso dos professores. In Ministério da Educação, Livro da Conferência 'Desenvolvimento profissional de professores para a qualidade e para a equidade da Aprendizagem ao longo da Vida' (pp. 21-28). Lisboa: Ministério da Educação.

Pastré, P. (2011). La didactique professionnelle. Approche anthropologique du développement chez les adultes. Paris: PUF.

Pineau, G. (2013). Les réflexions sur les pratiques au cœur du tournant réflexif. Éducation Permanente, n 196, 9-24.

Roche, J. (1999). Que faut-il entendre par professionnalisation?, Education Permanente, n0140/3, 35-49.

Sacristán, J. G. (Ed.) (2013). Saberes e Incertezas sobre o Currículo. Porto Alegre: Penso Editora, Ltda.

Schön, D. (1996). A la recherche d'une nouvelle épistémologie de la pratique et de ce qu'elle implique pour l'éducation des adultes. In J.-M. Barbier (Ed.), Savoirs Théoriques et Savoirs d'Action. (pp.201-222). Paris: PUF.

Silva, A. M. C. (2003). Formação, Percursos e Identidades. Coimbra: Quarteto Editora.

Silva, A. M. C. (2007). Formação: espaço-tempo de mediação na construção de identidades. Coimbra: Ariadne Editora.

Stroobants, M. (1994). La visibilité des compétences, in F. Ropé e L. Tanguy, Savoirs et Compétences. De l'usage de ces notions dans l'école et l'entreprise. (pp.175-203). Paris: L'Harmattan,

Tardif, M. (2000). Saberes profissionais dos professores e conhecimentos universitários. Elementos para uma epistemologia da prática profissional dos professores e suas consequências em relação à formação para o magistério. Revista Brasileira de Educação, $n^{0}$ $13,5-24$.

Tesch, R. (1990). Qualitative Research: Analysis types and software tools. New York: The Falmer Press.

Wittorski, R. (2008). La professionnalisation. Savoirs, n 17, 9-36

Zarifian, P. (1995). Le Travail et l'Événement. Paris: Éditions l'Harmattan.

Zeichener, K. M. (1993). A Formação Reflexiva de Professores: Ideias e Práticas. Lisboa: Educa. 